\title{
CHITINASE ACTIVITIES IN WHEAT AND ITS RELATIVE SPECIES
}

\author{
JANA MORAVČÍKOVÁ ${ }^{1 *}$, NIKOLETA UJVARIOVÁ ${ }^{2}$ IWONA ŽUR ${ }^{3}$, ZDENKA GÁLOVÁ², \\ ZUZANA GREGOROVÁ ${ }^{1}$, MÁRIA ZIMOVÁ ${ }^{1,4}$, EVA BOSZORÁDOVÁ $^{1}$, \\ ILDIKÓ MATUŠÍKOVÁ ${ }^{5}$
}

\author{
${ }^{1}$ Institute of Plant Genetics and Biotechnology Slovak Academy of Sciences, Nitra, Slovak Republic \\ ${ }^{2}$ Slovak University of Agriculture in Nitra, Slovak Republic \\ ${ }^{3}$ Polish Academy of Sciences the Franciszek Gorski Institute of Plant Physiology, Kraków, Poland \\ ${ }^{4}$ Constantine the Philosopher University in Nitra, Slovak Republic \\ ${ }^{5}$ University of SS. Cyril and Methodius, Trnava, Slovak Republic
}

MORAVČÍKOVÁ, J. - UJVARIOVÁ, N. - ŽUR, I. - GÁLOVÁ, Z. - GREGOROVÁ, Z. - ZIMOVÁ, M. - BOSZORÁDOVÁ, E. - MATUŠÍKOVÁ, I.: Chitinase activities in wheat and its relative species. Agriculture (Pol'nohospodárstvo), vol. 63, 2017, no. 1, pp. 14-22.

\begin{abstract}
Defense components such as chitinases (EC 3.2.1.14) are crucial for plants to cope diseases. Despite of that the pattern and activities of these enzymes in agronomically important Triticale is unexplored. This work is aimed to study chitinase activities in the leaves of plants of early developmental stages in two diploids (Aegilops tauschii Coss., Triticum monococcum L.), four tetraploids (Ae. cylindrical Host, Ae. triuncialis L., T. araraticum Jakubyz, T. dicoccum Schrank) and two hexaploids (T. aestivum L., T. spelta L.). The leaves were subjected to quantitative and qualitative activity assays using synthetic 4-methylumbelliferyl- $\beta$-D- $N, N^{\prime}, N^{\prime \prime}$-triacetylchitotrioside and glycolchitin as substrates, respectively. Our results showed that the activities of chitinases with specificity towards short oligomers were variable and genotype dependent. The enzyme activities in the tetra- and hexaploid genotypes were significantly higher than in diplod counterparts. In the gel detection assays were revealed up to four fractions $(\sim 20,30,42$ and $95 \mathrm{kDa})$ of proteins with the chitinase activity towards long chain polymers. The isoform of $\sim 30 \mathrm{kDa}$ was identified in all analyzed genotypes. Among the seven acidic and three basic chitinase fractions identified, three acidic (ChiA, $\mathrm{ChiB}, \mathrm{ChiC})$ and two (ChiH, ChiI) fractions were present in all genotypes. None of the isoforms can be assigned as specific with respect to ploidy.
\end{abstract}

Key words: defense proteins, hydrolases, glycolchitin, chitinases, ploidy, PR protein, wheat

Chitinases are widely distributed enzymes in plants. Plant chitinases (EC 3.2.1.14) hydrolyze $\beta-1,4-N$-acetyl-D-glucosamine (GlcNAc) linkages of chitin. Their true substrate in plants is unknown since they lack chitin, but chitinases are suggested to cleave arabinogalactan proteins (AGPs) and $\mathrm{N}$-acetylglucosamine-containing glycoproteins in the plant cell walls (van Hengel et al. 2001; van

Ing. Jana Moravčíková, PhD. (*Corresponding author), Ing. Eva Boszorádová, PhD., Zuzana Gregorová, PhD., Institute of Plant Genetics and Biotechnology Slovak Academy of Sciences, Akademická 2, P.O. Box 39A, 950 07 Nitra, Slovak Republic. E-mail: jana.moravcikova@savba.sk, eva.boszoradova@savb.sk, zuzana.gregorova@ savba.sk

prof. RNDr. Zdenka Gálová, CSc., Ing. Nikoleta Ujváriová, Slovak University of Agriculture in Nitra, Faculty of Biotechnology and Food Science, A. Hlinku 2, 94976 Nitra, Slovak Republic. E-mail: zdenka.galova@uniag.sk, nikoleta115@gmail.com

Dr. hab. Iwona Žur, Dip. eng. Polish Academy of Sciences the Franciszek Gorski Institute of Plant Physiology, Niezapominajek 21, PL-30-239 Kraków, Poland. E-mail: i.zur@ifr-pan.edu.pl

Ing. Mária Zimová, Department of Botany and Genetics, Faculty of Natural Sciences, Constantine the Philosopher University in Nitra, Nábrežie mládeže 91, 94974 Nitra, Slovak Republic. E-mail: majuska.zimova@gmail.com Mgr. Ildikó Matušíková, PhD., Department of Ecochemistry and Radioecology, University of SS. Cyril and Methodius, J. Herdu 2,91701 Trnava, Slovak Republic. E-mail: ildiko.matusikova@ucm.sk 
Hengel et al. 2002). Afterwards, the released substances can act as an elicitor of plant defence response (Fessel \& Zuccaro 2016). Chitinases that are induced in response to pathogen attack are also referred as "Pathogenesis related proteins" (PR3, PR4, PR8 and PR11) (Kasprzewska 2003). They were shown to inhibit fungal growth in vitro (SelaBuurlage et al. 1993), while their over-expression in transgenic plants enhanced fungal resistance (Moravcikova et al. 2004).

According to the CAZy database chitinases form two glycoside hydrolase families GH18 and GH19 which show different structures and catalytic mechanisms. The family GH19 chitinases are mainly found in plants. Based on their amino acid composition, plant chitinases are mainly grouped into five classes (Neuhaus 1999). The classes I, II and IV belong to the family GH19 while III and V to the family GH18. These enzymes can be expressed in plants constitutively (Colligne et al. 1993) or they can be induced upon pathogen infection (Žur et al. 2013), low temperature (Yeh et al. 2000), ethylene (Zhong et al. 2002), drought (Gregova et al. 2015) or heavy metals (Meszaros et al. 2014). Besides, it was suggested that they might take part in programmed cell death (Kim et al. 2015). Chitinases could also play a role in developmental processes such us pollination, senescence, seed germination and somatic embryogenesis (Kasprzewska 2003; Grover 2012).

Bread wheat is one of the most important grain crops worldwide. Its hexaploid genome is a result of the evolutionary hybridization, domestication and/ or selection steps. However, genetic improvement for human purposes caused genetic erosion and increased susceptibility to environmental and biotic stresses. Not surprisingly that some wild ancestors and inter-crossable wheat relatives are more resistant to some disease than bread wheat (Peng et al. 2011).

In this work we studied the activities of chitinases in two wheat ( $T$. aestivum L., T. spelta L.) and crop relative species (Aegilops tauschii Coss., Ae. cylindrical Host, Ae. triuncialis L., T. monococcum L., T. araraticum Jakubyz, T. dicoccum Schrank). Qualitative and quantitative chitinase activity assays were used to reveal in detail the profile and activities of individual isoforms in wheat and wild relative species at early developmental stage.

\section{MATERIAL AND METHODS}

\section{Plant material}

Seeds of eight wheat genotypes (Table 1) were obtained from the Gene Bank of the Slovak Republic (National Agricultural and Food Centre, Slovak Republic). The seeds were germinated on the watered sterile filter paper in dark at room temperature for 3 days. Then, germinated seeds were transferred to the pots with the commercial substrate BORA and cultivated at $22^{\circ} \mathrm{C}$ and $16 \mathrm{~h} / 8 \mathrm{~h}$ light/dark photoperiod under $50 \mu \mathrm{E} / \mathrm{m}^{2} / \mathrm{s}$ light intensity for 3 weeks. The leaves of wheat plants (10 plants/genotype) at two leaf stage (Zadoks stage 12) were collected and used for analyses.

\section{Protein extraction}

Crude protein extracts were isolated from the leaves of plants using an extraction buffer that contained $0.1 \mathrm{~mol} / \mathrm{dm}^{3}$ sodium acetate $(\mathrm{pH} \mathrm{5.0)}$ and $0.02 \%(\mathrm{v} / \mathrm{v}) \beta-$ mercaptoethanol according to the protocol described previously (Žur et al. 2013). Protein concentration was determined according to Bradford (1976).

\section{Gel electrophoresis and chitinase activity staining}

Protein extracts $(30 \mu \mathrm{g})$ were separated on $12.5 \%(\mathrm{w} / \mathrm{v})$ SDS-containing polyacrylamide slab gels (Laemmli 1970) with $0.01 \%$ (w/v) glycol chitin as an enzyme substrate. Glycol chitin was obtained by acetylation of glycol chitosan (Sigma G-7753) as described by Trudel and Asselin (1989). The gels were run at $8^{\circ} \mathrm{C}$ at a constant voltage of $120 \mathrm{~V}$ for $2 \mathrm{~h}$. After electrophoresis, proteins were re-naturated by shaking the gel in $50 \mathrm{mmol} / \mathrm{dm}^{3}$ sodium acetate buffer ( $\mathrm{pH} 5.0$ ), 1\% (v/v) Triton X-100 for 1 hour.

Separation of proteins under native conditions (for acidic/neutral or basic/neutral proteins) was performed according to Konotop et al. (2012) using $11 \%(\mathrm{w} / \mathrm{v})$ acrylamide gels with $0.01 \%(\mathrm{w} / \mathrm{v})$ glycol chitin.

The chitinase activity was detected by staining with $0.01 \%$ (w/v) Fluorescent Brightener 28 (Pan et al. 1991).

\section{Chitinase quantitative assays}

The chitinase activity was assayed fluorimetrically using the synthetic substrate 4-methylumbelliferyl- $\beta-\mathrm{D}-\mathrm{N}, \mathrm{N}^{\prime}, \mathrm{N}^{\prime \prime}$-triacetylchitotrioside [4-MU- 
(GlcNAc) ${ }_{3}$ (Fluka 69615) as was described previously (Libantova et al. 2009). The fluorescence was measured using excitation/emission filters $360 \mathrm{~nm} / 450 \mathrm{~nm}$ (Synergy H1,Bioetek). The chitinase activity was expressed in picomoles of methylumbelliferone (4-MU) generated per hour per milligram of soluble proteins.

The shown data represent the means of three replications. Statistical significance of the experimental results was evaluated by ANOVA/MANOVA and Duncan's tests, with help of STATISTICA ${ }^{\circledR}$ version 7.1.

\section{RESULTS AND DISCUSSION}

Chitinases from different plant species have been studied mainly for their inducibility upon biotic stresses. Their role in plant growth and development has also been proven. However, there are still limited information about chitinases in wheat and its relative species. So far, the Uniprot and NCBI databases contain up to 18 characterized sequences concerning chitinases in the hexaploid $T$. aestivum
L. (Table 2). In literature, wheat chitinases were studied mainly for their antifungal potential (Liao et al. 1994; Caruso et al. 1999; Li et al. 2001; Kong et al. 2005), drought stress (Gregorova et al. 2015), heavy metal accumulation (Lyubka et al. 2008) or different concentration of nitrogen as a nutritional supply (Maglovski et al. 2017).

In this work we studied the activities of chitinases in wheat and relative species (Table 1). The plants were grown under controlled conditions up to two leaf stage. Afterwards, the leaves were collected and subjected to the chitinase activity assays.

The enzyme activities were evaluated quantitatively based on the ability of plant chitinases to release (GlcNAc) ${ }_{3}$ from the tetramer 4MU-(GlcNAc), a fluorogenic substrate for short oligomer-specific endochitinases. Our results showed that chitinases with hydrolytic activity towards oligomers were active in all analysed genotypes. Data are summarized in Figure 1a. The effect of genotype was found to be significant (at $p \leq 0.001$ ). The highest chitinase activity was detected for T. diccocum Schrank $(59.05 \mathrm{nmol}$ $\mathrm{MU} / \mathrm{h} / \mathrm{mg}$ ) and the lowest ones for T. monococcum $\mathrm{L}$. (5.89 nmol MU/h/mg) and Ae. tauschii Coss. (7.96

$\begin{array}{lllllllllll}\mathrm{T} & \mathrm{a} & \mathrm{b} & 1 & \mathrm{e} & 1\end{array}$

Wheat and crop relatives species used in the experiments and their resistance to important wheat diseases

\begin{tabular}{|c|c|c|c|c|c|c|}
\hline \multirow[b]{2}{*}{ Genotype } & \multicolumn{6}{|c|}{ Disease resistance ${ }^{*}$} \\
\hline & Gene bank $^{* *}$ & $\begin{array}{l}\text { Ploidy/ } \\
\text { Genome }\end{array}$ & $\begin{array}{l}\text { Powdery } \\
\text { mildew } \\
\text { Leaf/spike }\end{array}$ & $\begin{array}{c}\text { Wheat rust } \\
\text { leaf }\end{array}$ & $\begin{array}{c}\text { Take-all of } \\
\text { wheat }\end{array}$ & $\begin{array}{c}\text { Blotch of } \\
\text { wheat }\end{array}$ \\
\hline Aegilops cylindrical Host & $\begin{array}{l}\text { ARME } \\
\text { N06-02 }\end{array}$ & $\begin{array}{c}\text { Tetraploid } \\
\text { CCDD }\end{array}$ & $9 / 9$ & 1 & 9 & 9 \\
\hline Aegilops tauschii Coss. & $\begin{array}{l}\text { ARME } \\
\text { N06-40 }\end{array}$ & Diploid DD & $9 / 9$ & 1 & 9 & 9 \\
\hline Aegilops triuncialis L. & $\begin{array}{l}\text { ARME } \\
\text { N06-06 }\end{array}$ & $\begin{array}{l}\text { Tetraploid } \\
\text { UUCC }\end{array}$ & $9 / 9$ & 9 & 9 & 9 \\
\hline Triticum aestivum $\mathrm{L}$. & Astella & $\begin{array}{l}\text { Hexaploid } \\
\text { BBAA }^{u} \text { DD }\end{array}$ & $5 / 5$ & 7 & 8 & 8 \\
\hline Triticum araraticum Jakubyz & $\begin{array}{c}\text { AZESVK } \\
2009-47\end{array}$ & $\begin{array}{c}\text { Tetraploid } \\
\text { GGAA }^{u}\end{array}$ & $7 / 6$ & 5 & 8 & 8 \\
\hline Triticum dicoccum Schrank & $\begin{array}{c}\text { AZESVK } \\
2009-78\end{array}$ & $\begin{array}{c}\text { Tetraploid } \\
\text { BBAA }^{u}\end{array}$ & $8 / 7$ & 6 & 6 & 6 \\
\hline Triticum monococcum $\mathrm{L}$. & $\begin{array}{c}\text { AZESVK } 2 \\
009-84\end{array}$ & Diploid $\mathrm{AA}^{\mathrm{m}}$ & $9 / 9$ & 8 & 9 & 9 \\
\hline Triticum spelta $\mathrm{L}$. & Brun 5/9 & $\begin{array}{l}\text { Hexaploid } \\
\text { BBAA" DD }^{u}\end{array}$ & $4 / 6$ & 5 & 9 & 9 \\
\hline
\end{tabular}

*Disease severity rating based on the data obtained from the Gene Bank of the Slovak Republic; 9 - very high resistance, 1 - very low resistance

${ }^{* *}$ Accession number in the Gene bank of the Slovak Republic 
$\mathrm{nmol} \mathrm{MU} / \mathrm{h} / \mathrm{mg}$ ). The activities in the tetraploid and hexaploid species were significantly higher than in the diploid species (at $p \leq 0.01$ ) (Figure 1b). It might coincide with successive polyploidization of wheat genome since such genomic can reprogram gene expression patterns (Chen et al. 2007).
As is shown in Table 1 the analysed wheat relatives were evaluated as more resistant to the selected fungal diseases. However, no correlation between chitinase activities and disease severity rating was observed. Chitinases are multifunctional enzymes that take part not only in plant pathogenesis but

a)

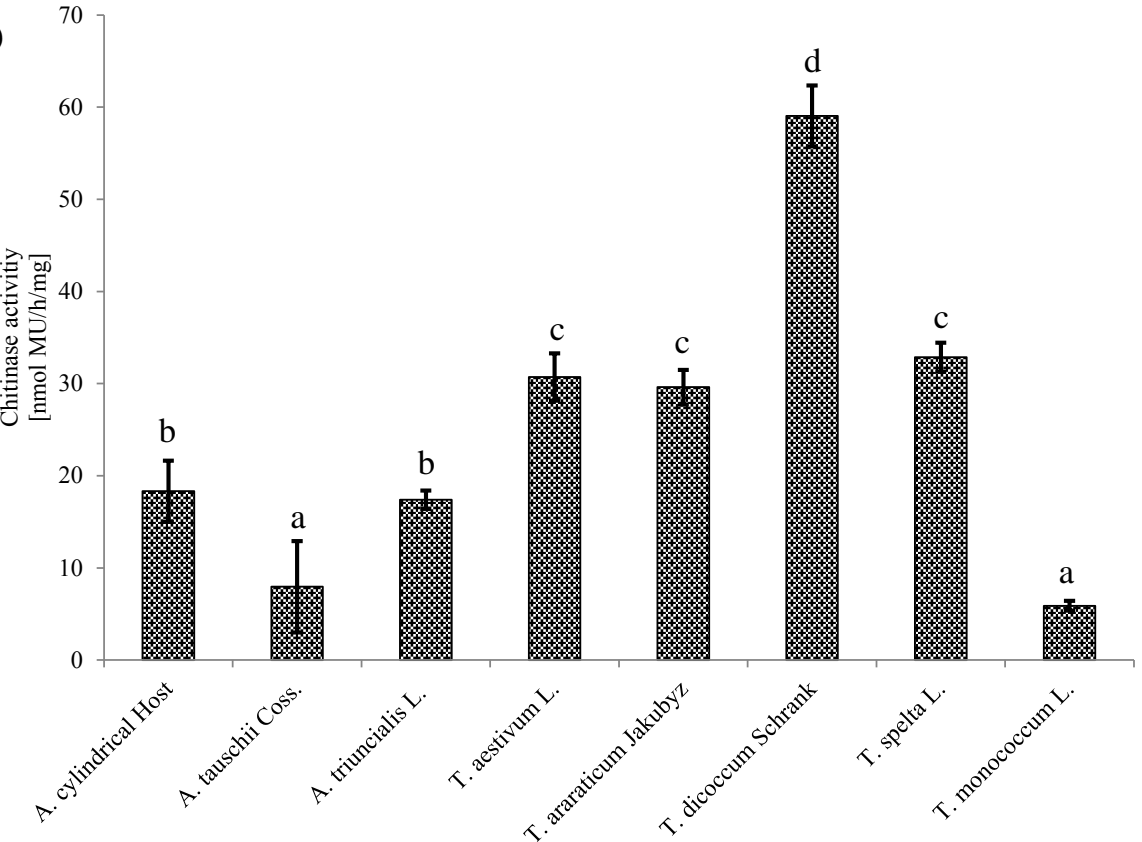

b)

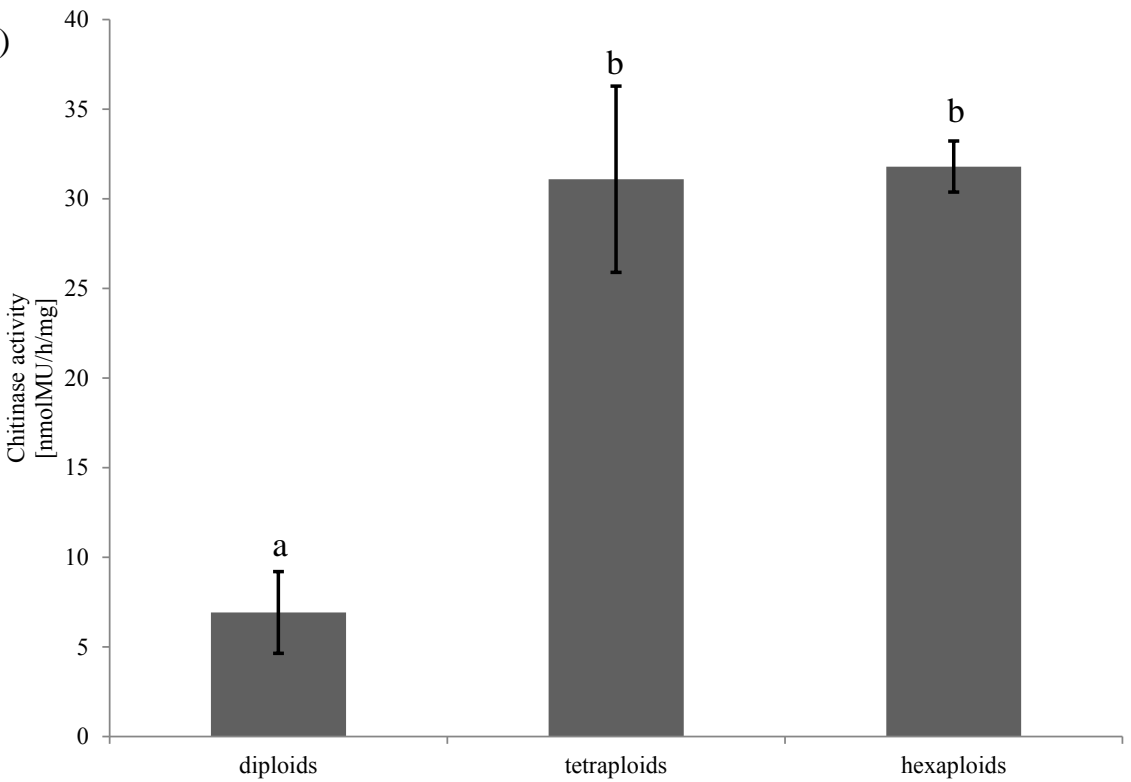

Figure 1. Chitinase activities in the studied wheat and its (wild) relatives (a) and in dependence on ploidy level (b). The enzyme activities were assayed fluorimetrically using [4-MU-(GlcNAc) ${ }_{3}$ ] as a substrate. The activity was expressed in nmol of methylumberylferone (MU) released per hour per mg of soluble proteins. Bars represent means \pm standard deviations of three replications. Distinct letters denote statistically significant differences with Duncan's test at $p \leq 0.001$ (a) and at $p \leq 0.01$ (b). 


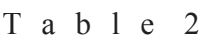

Chitinases in T. aestivum L. and their characterization based on the data in the NCBI and UNIPROT databases (September 2016)

\begin{tabular}{|c|c|c|c|c|c|c|}
\hline $\begin{array}{l}\text { UNIPROT/ } \\
\text { NCBI }\end{array}$ & Name & AA & $\begin{array}{l}\mathrm{MW} \\
{[\mathrm{kDa}]}\end{array}$ & $\begin{array}{l}\text { DNA } \\
{[\mathrm{bp}]}\end{array}$ & Description/function & Literature \\
\hline $\begin{array}{l}\text { Q8W427/ } \\
\text { AB029936 }\end{array}$ & $\begin{array}{l}\text { Chitinase 3, Chi3 } \\
\text { cht1 }\end{array}$ & 319 & 33.5 & 960 & $\begin{array}{l}\text { Biotic stress } \\
\text { Puccinia striiformis West.f. sp. } \\
\text { tritici }\end{array}$ & - \\
\hline $\begin{array}{l}\text { Q8W428/ } \\
\text { AB029935 }\end{array}$ & $\begin{array}{l}\text { Chitinase 2, Chi2 } \\
\text { Chitinase } 2\end{array}$ & 323 & 34.2 & 1,163 & - & - \\
\hline $\begin{array}{l}\text { A0A0H4TIG5/ } \\
\text { KR049249 }\end{array}$ & $\begin{array}{l}\text { Chitinase } \\
\text { Chitinase, cht3 }\end{array}$ & 317 & 33.4 & 954 & $\begin{array}{l}\text { Biotic stress } \\
\text { P. striiformis West.f. sp. tritici }\end{array}$ & - \\
\hline $\begin{array}{l}\text { Q6T484/ } \\
\text { AY437443 }\end{array}$ & $\begin{array}{l}\text { Class I, } \\
\text { chitinase Class I, } \\
\text { chitinase }\end{array}$ & 319 & 33.5 & 1,121 & $\begin{array}{l}\text { Botic stress } \\
\text { Fusarium graminearum }\end{array}$ & Kong et al. (2005) \\
\hline $\begin{array}{l}\text { Q8W429/ } \\
\text { AB029934 }\end{array}$ & $\begin{array}{l}\text { Chitinase } 1 \text {, } \\
\text { Chi } 1 \\
\text { Chitinase } 1 \\
\end{array}$ & 256 & 27.1 & 979 & - & - \\
\hline $\begin{array}{l}\text { Q4Z8L7/ } \\
\text { AY973230 }\end{array}$ & $\begin{array}{l}\text { Class II, chitinase } \\
\text { Class II, chitinase }\end{array}$ & 266 & 28.3 & 811 & Seed development & - \\
\hline $\begin{array}{l}\text { Q4Z8L8/ } \\
\text { AY973229 }\end{array}$ & $\begin{array}{l}\text { class II, chitinase } \\
\text { class II,chitinase }\end{array}$ & 266 & 28.2 & 892 & Seed development & - \\
\hline $\begin{array}{l}\text { A0A0H4TM98/ } \\
\text { KR049250 }\end{array}$ & $\begin{array}{l}\text { Chitinase cht } 4 \text {, } \\
\text { chitinase }\end{array}$ & 320 & 33.6 & 963 & $\begin{array}{l}\text { Biotic stress } \\
\text { P. striiformis West.f. sp. tritici }\end{array}$ & - \\
\hline $\begin{array}{l}\text { A0A077RF77/ } \\
\text { KR049248 }\end{array}$ & $\begin{array}{l}\text { Chitinasecht } 2 \text {, } \\
\text { chitinase }\end{array}$ & 320 & 33.6 & 963 & $\begin{array}{l}\text { Biotic stress } \\
\text { P. striiformis West.f. sp. tritici }\end{array}$ & - \\
\hline $\begin{array}{l}\text { Q9XEN3/ } \\
\text { AF112963 }\end{array}$ & $\begin{array}{l}\text { Chitinase II, Cht } 2 \\
\text { Chitinase II, Cht } 2\end{array}$ & 230 & 24.7 & 956 & $\begin{array}{l}\text { Biotic stress } \\
\text { F. graminearum }\end{array}$ & Li et al. (2001) \\
\hline Q41539/X76041 & $\begin{array}{l}\text { Endochitinase CHI } \\
\text { Endochitinase CHI }\end{array}$ & 320 & 33.6 & 1,985 & $\begin{array}{l}\text { Biotic stress } \\
\text { P. graminis }\end{array}$ & Liao et al. (1994) \\
\hline $\begin{array}{l}\text { A0A023W638/ } \\
\text { KJ507390 }\end{array}$ & $\begin{array}{l}\text { Endochitinase } \\
\text { Endochitinase }\end{array}$ & 320 & 33.6 & 963 & - & - \\
\hline $\begin{array}{l}\text { A0A023W4F1/ } \\
\text { KJ507387 }\end{array}$ & $\begin{array}{l}\text { Endochitinase } \\
\text { Endochitinase }\end{array}$ & 318 & 33.5 & 957 & - & - \\
\hline $\begin{array}{l}\text { A0A023W636/ } \\
\text { KJ507385 }\end{array}$ & $\begin{array}{l}\text { Endochitinase } \\
\text { Endochitinase }\end{array}$ & 319 & 33.5 & 960 & - & - \\
\hline $\begin{array}{l}\text { A0A023W5U7/ } \\
\text { KJ507389 }\end{array}$ & $\begin{array}{l}\text { Endochitinase } \\
\text { Endochitinase }\end{array}$ & 320 & 33.6 & 963 & - & - \\
\hline $\begin{array}{l}\text { A0A023W4N4/ } \\
\text { KJ507388 }\end{array}$ & $\begin{array}{l}\text { Endochitinase } \\
\text { Endochitinase }\end{array}$ & 318 & 35.3 & 957 & - & - \\
\hline $\begin{array}{l}\text { A0A023W594/ } \\
\text { KJ507386 }\end{array}$ & $\begin{array}{l}\text { Endochitinase } \\
\text { Endochitinase }\end{array}$ & 317 & 33.5 & 954 & - & - \\
\hline
\end{tabular}

AA - amino acids; MW - molecular weight 
also they regulate processes of plant growth and development. It has been reported that upon (a)biotic stresses the activities of some constitutively synthesized chitinases can be increased (Žur et al. 2013).

The activities measured comprise several individual isoforms with different activities and functions. Therefore the substrate glycol chitin was used to detect chitinases with hydrolytic activities towards long polymers after their separation in gels. Our analyses identified up to four enzyme fractions $(\sim 20,30,42$ and $95 \mathrm{kDa})$ with the chitinolytic activities (Figure $2 \mathrm{~b}$, Table 3 ). Only the $\sim 30 \mathrm{kDa}$ fraction was identified in all analysed genotypes. For comparison, the purified wheat chitinases in the sequence databases are of molecular mass in a range between $27 \mathrm{kDa}$ to $36 \mathrm{kDa}$ (Table 2). The molecular mass of plant chitinases commonly ranges from $25 \mathrm{kDa}$ to $35 \mathrm{kDa}$, but plant isoforms of $20 \mathrm{kDa}$ or $\geq 40 \mathrm{kDa}$ were also described (Chang et al. 2014). Most plant chitinases of $30-46 \mathrm{kDa}$ are referred as PR proteins (Ferreira et al. 2007) thus the identified chitinase isoforms of $\sim 30 \mathrm{kDa}$ and $\sim 42 \mathrm{kDa}$ might be significantly induced upon (a)biotic stresses.

Plant chitinases have been found to exist in acidic and basic forms according to their isoelectric points (Kasprzewska 2003). Based on the classification by Stintzi et al. (1993) the acidic isoforms are considered as extracellular while basic as vacuolar. We identified up to seven acidic (ChiA-ChiG) (Figure 2c) and three basic (Figure 2d) fractions with hydrolytic activities towards the long polymer glycolchitin (Table 3). The three acidic (ChiA, ChiB, ChiC) and two (ChiH, ChiI) isoforms were detected in all genotypes. In most of analysed genotypes, combination of four acidic fractions was found. However, none of the acidic isoforms can be associated with ploidy level.

Our results (Figure 1, Figure 2) showed that chitinases with specificities towards short oligomers and long chitin polymers are accumulated in the leaves of all analysed genotypes. The genotype had significant effect on short oligomer-specific chitinase ac-

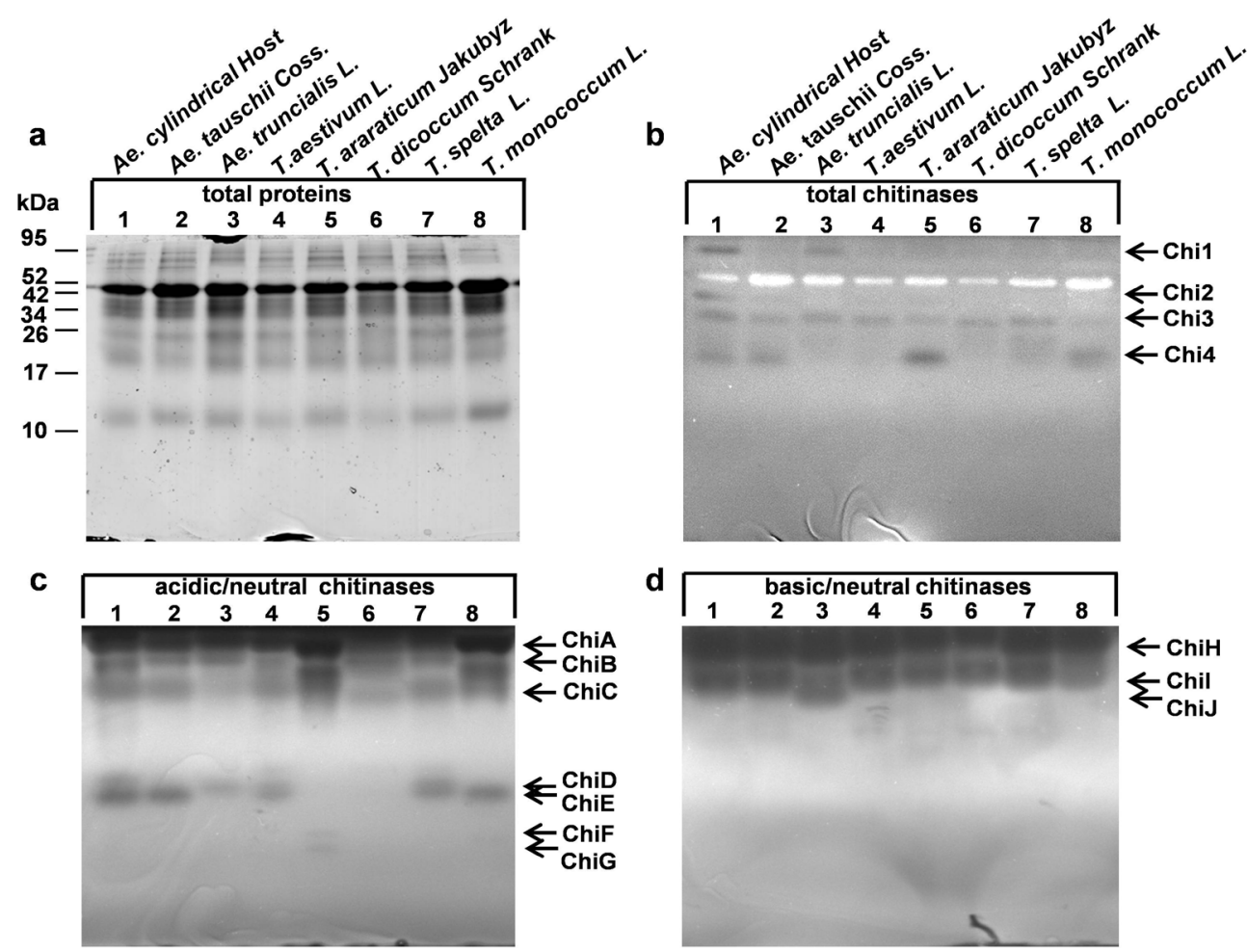

Figure 2. Detection of chitinase activities after separation of crude protein extracts in the SDS-PAGE. Proteins were isolated from plants and their amount and quality was checked upon visualization with Coomassie Brilliant Blue R 250 (a). For activity detection towards glycolchitin as a substrate they were separated under semi-denaturing conditions based on the size (b) and under native conditions in the PAGE for acidic/neutral (c) and basic/neutral proteins (d). Numbers on the left refer to the molecular mass marker. Arrows indicate the detected isoforms. 
tivities. These activities were significantly higher in tetra- and hexaploid than in diploid genotypes. The enzymes with hydrolytic activities towards oligomers and chitin polymers possess a potential for production of biologically active substances with antibacterial, antifungal, antitumor or immunity-enhancing effects (Li et al. 2016).

\section{CONCLUSIONS}

The activities of chitinases in two hexaploid wheat ( $T$. aestivum L., $T$. spelta L.) and six their crop relative species (Ae. tauschii Coss., Ae. cylindrical Host, Ae. triuncialis L., T. monococcum L., T. araraticum Jakubyz, $T$. dicoccum Schrank) were studied. Our results showed that chitinases are active in the leaves of all analysed genotypes, while the gained values were variable and dependent on genotype. The activities in the tetra- and hexaploid genotypes appeared significantly higher than in their diplod counterparts. The gel activity assays revealed up to four fractions of proteins with chitinase activity of which the isoform Chi3 of $\sim 30 \mathrm{kDa}$ was identified in all analysed genotypes. More detailed analyses detected up to seven acidic and three basic

T a b 1 e 3

Overview of the chitinase activities in wheat and its relative species

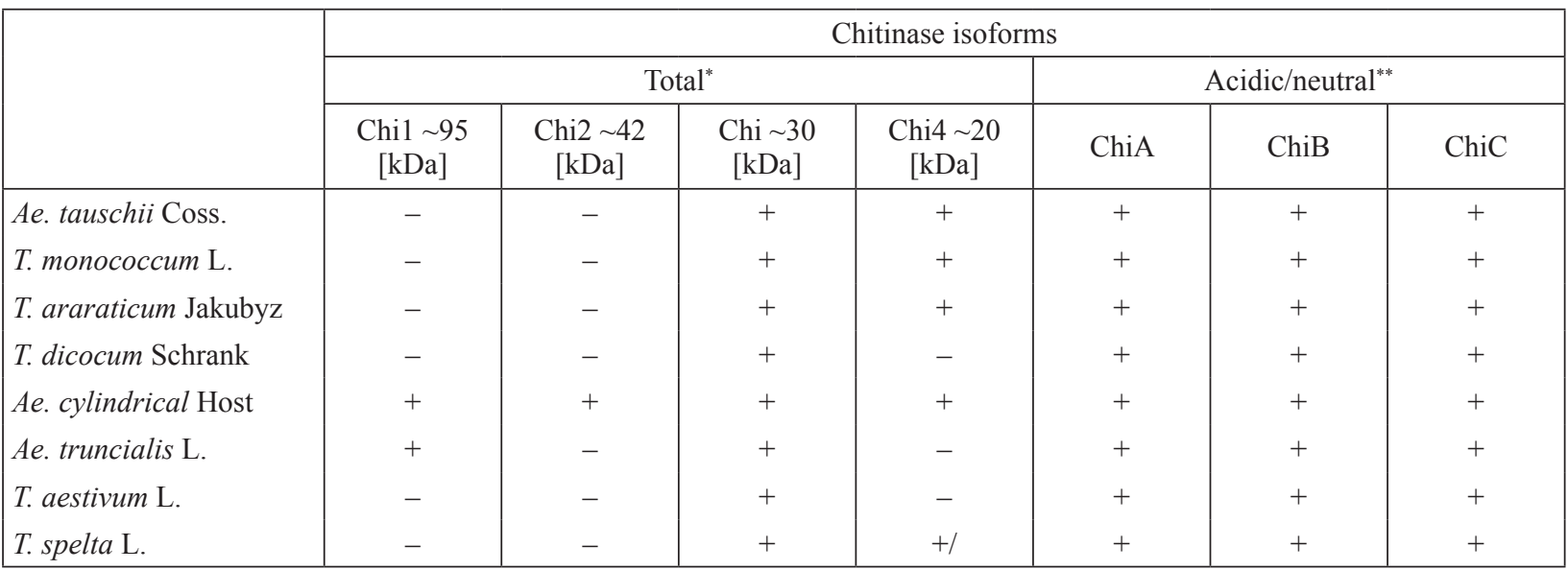

Table 3 continued

\begin{tabular}{|c|c|c|c|c|c|c|c|}
\hline & \multicolumn{7}{|c|}{ Chitinase isoforms } \\
\hline & \multicolumn{4}{|c|}{ Total $^{*}$} & \multicolumn{3}{|c|}{$\mathrm{Basic}_{\text {/neutral }}{ }^{* * *}$} \\
\hline & ChiD & ChitE & ChiF & ChiG & ChiH & Chil & ChiJ \\
\hline Ae. tauschii Coss. & - & + & - & - & + & + & - \\
\hline T. monococcum L. & - & + & - & - & + & + & - \\
\hline T. araraticum Jakubyz & - & - & + & + & + & + & - \\
\hline T. dicocum Schrank & - & - & - & - & + & + & - \\
\hline Ae. cylindrical Host & + & + & - & - & + & + & - \\
\hline Ae. truncialis L. & + & - & - & - & + & + & + \\
\hline T. aestivum L. & + & - & - & - & + & + & - \\
\hline T. spelta L. & + & - & - & - & + & + & - \\
\hline
\end{tabular}

${ }^{*}$ Size of the isoforms (Chi1-Chi4) detected in the gel after re-naturation of separated proteins in the SDS-PAGE (Figure 2b)

** Fractions detected in the gel after separation of proteins in the PAGE under conditions for acidic/neutral proteins (Figure 2c)

${ }^{* * *}$ Fractions detected in the gel after separation of the proteins in the PAGE under conditions for basic/neutral proteins (Figure 2d) 
enzyme fractions of which some were specific for individual genotypes. However, a larger set has to be studied to assign them with respect to ploidy level. The presence of additional isoforms in the wild relatives of wheat brings a promise for identifying novel sources of defence compounds potentially interesting for breeding purposes. Besides, wheat chitinases can be studied for potential use in biotechnological programs focused on production of bioactive chitoologosacharides.

Acknowledgements. This work was supported by the bilateral project APVV SK-PL-2015-044, by the project APVV-15-0051, UGA VIII/32/2017 and by the Operational programme Research and Development for the project: 'Implementation of the research of plant genetic resources and its maintaining in the sustainable management of Slovak republic' (ITMS: 26220220097), co-financed from the resources of the European Union Fund for Regional Development.

\section{REFERENCES}

BRADFORD, M.M. 1976. A rapid and sensitive method for the quantitation of microgram quantities of protein utilizing the principle of protein-dye binding. In Analytical biochemistry, no. 72, pp. 248-254.

CARUSO, C. - BERTINI, L. - TUCCI, M. - CAPORALE, C. - LEONARDI, L. - SACCARDO, F. - BRESSAN, R.A. VERONESE, P. - BUONOCORE, V. 1999. Isolation and characterisation of wheat cDNA clones encoding PR4 proteins. In DNA Sequence, vol. 10, no. 4-5, pp. 301-307.

COLLINGE, D.B. - KRAGH, K.M. - MIKKELSEN, J.D. NIELSEN, K.K. - RASMUSSEN, U. - VAD, K. 1993. Plant chitinases. In Plant Journal, vol. 3, no. 1, pp. 31-40.

FERREIRA, R.B. - MONTEIRO, S. - FREITAS, R. SANTOS, C.N. - CHEN, Z. - BATISTA, L.M. - DUARTE, J. - BORGES, A. - TEIXEIRA, A.R. 2007. The role of plant defence proteins in fungal pathogenesis. In Molecular Plant Pathology, vol. 8, no. 5, pp. 677-700.

FESEL, P.H. - ZUCCARO, A. 2016. Beta-glucan: Crucial component of the fungal cell wall and elusive MAMP in plants. In Fungal Genetics and Biology, no. 90, pp. 53-60.

GREGOROVA, Z. - KOVACIK, J. - KLEJDUS, B. MAGLOVSKI, M. - KUNA, R. - HAUPTVOGEL, P. MATUSIKOVA, I. 2015. Drought-induced responses of physiology, metabolites, and pr proteins in Triticum aestivum. In Journal of Agricultural and Food Chemistry, vol. 63, no. 37, pp. 8125-8133.

GROVER, A. 2012. Plant Chitinases: Genetic Diversity and Physiological Roles. In Critical Reviews in Plant Sciences, vol. 31 , no. 1, pp. 57-73.

CHANG, Y.M. - CHEN, L.C. - WANG, H.Y. - CHIANG, C.L. - CHANG, C.T. - CHUNG, Y.C. 2014. Characterization of an Acidic Chitinase from Seeds of Black Soybean (Glycine max (L) Merr Tainan No. 3). In Plos One, vol. 9, no. 12, http//dx.doi.org/10.1371/journal.pone.0113596

CHEN, Z.J. 2007. Genetic and epigenetic mechanisms for gene expression and phenotypic variation in plant polyploids. In Annual Review of Plant Biology, no. 58, pp. 377-406.

KASPRZEWSKA, A. 2003. Plant chitinases - regulation and function. In Cellular \& Molecular Biology Letters, vol. 8, no. 3, pp. 809-824.

KIM, D.S. - KIM, N.H. - HWANG, B.K. 2015.The Capsicum annuum class IV chitinase ChitIV interacts with receptor-like cytoplasmic protein kinase PIK1 to accelerate PIK1-triggered cell death and defence responses. In Journal of Experimental Botany, vol. 66, no. 7, pp. 1987-1999.

KONG, L. - ANDERSON, J.M. - OHM, H.W. 2005. Induction of wheat defense and stress-related genes in response to Fusarium graminearum. In Genome, vol. 48, no. 1, pp. 29-40.

KONOTOP, Y. - MESZAROS, P. - SPIESS, N. - MISTRIKOVA, V. - PIRSELOVA, B. - LIBANTOVA, J. - MORAVCIKOVA, J. - TARAN, N. - HAUPTVOGEL, P. - MATUSIKOVA, I. 2012. Defense responses of soybean roots during exposure to cadmium, excess of nitrogen supply and combinations of these stressors. In Molecular Biology Reports, vol. 39, no. 12, pp. 10077-10087.

LAEMMLI, U.K. 1970. Cleavage of structural proteins during the assembly of the head of bacteriophage T4. In Nature, vol. 227 , no. 5259 , pp. 680-685.

LI, K. - XING, R. - LIU, S. - LI, P. 2016. Advances in preparation, analysis and biological activities of single chitooligosaccharides. In Carbohydrate Polymers, no. 139, pp. 178-190.

LI, W.L. - FARIS, J.D. - MUTHUKRISHNAN, S. - LIU, D.J. - CHEN, P.D. - GILL, B.S. 2001. Isolation and characterization of novel cDNA clones of acidic chitinases and beta-1,3-glucanases from wheat spikes infected by Fusarium graminearum. In Theoretical and Applied Genetics, vol. 102, no. 2-3, pp. 353-362.

LIAO, Y.C. - KREUZALER, F. - REISENER, H.J. - TIBURZY, R. - FISCHER, R. 1994. Characterization of a wheat class ibchitinase gene differentially induced in isogenic lines by infection with Puccinia-graminis. In Plant Science, vol. 103, no. 2 , pp. $177-187$.

LIBANTOVA, J. - KAMARAINEN, T. - MORAVCIKOVA, J. - MATUSIKOVA, I. - SALAJ, J. 2009. Detection of chitinolytic enzymes with different substrate specificity in tissues of intact sundew (Drosera rotundifolia L.). In Molecular Biology Reports, vol. 36, no. 5, pp. 851-856.

LYUBKA, K. - DONKA, S. - IVANKA, Y. - TSVETANKA, B. - ANDON, V. 2008. Characterization of cadmium uptake by roots of durum wheat plants. In Journal of Central European Agriculture, vol. 9, no. 3, pp. 533-537.

MAGLOVSKI, M. - GREGOROVÁ, Z. - RYBANSKÝ, L. MÉSZÁROS, P. - MORAVČÍKOVÁ, J. - HAUPTVOGEL, P. - ADAMEC, L. - MATUŠÍKOVÁ, I. 2017. Nutrition supply affects the activity of pathogenesis-related $\beta-1,3$-glucanases and chitinases in wheat. In Plant Growth Regulation, vol. 81 , no. 3, pp. 443-453.

MESZAROS, P. - RYBANSKY, L. - SPIESS, N. - SOCHA, P. - KUNA, R. - LIBANTOVA, J. - MORAVCIKOVA, J. PIRSELOVA, B. - HAUPTVOGEL, P. - MATUSIKOVA, I. 2014. Plant chitinase responses to different metal-type stresses reveal specificity. In Plant Cell Reports, vol. 33, no. 11, pp. 1789-1799.

MORAVCIKOVA, J. - MATUSIKOVA, I. - LIBANTOVA, J. - BAUER, M. - MLYNAROVA, L. 2004. Expression of a cucumber class III chitinase and Nicotiana plumbaginifolia class I glucanase genes in transgenic potato plants. In Plant Cell Tissue and Organ Culture, vol. 79, no. 2, pp. 161-168. 
NEUHAUS, J.M. - FRITIG, B. - LINTHORST, H.J.M. MEINS, F. - MIKKELSEN, J.D. - RYALS, J. 1996. A revised nomenclature for chitinase genes. In Plant Molecular Biology Reporter, vol. 14, no. 2, pp. 102-104.

PAN, S.Q. - YE, X.S. - KUC, J. 1991. A technique for detection of chitinase, beta-1,3-glucanase, and protein-patterns after a single separation using polyacrylamide-gel electrophoresis or isoelectrofocusing. In Phytopathology, vol. 81, no. 9, pp. 970-974.

PENG, J.H. - SUN, D. - NEVO, E. 2011. Domestication evolution, genetics and genomics in wheat. In Molecular Breeding, vol. 28, no. 3, pp. 281-301.

SELA-BUURLAGE, M.B. - PONSTEIN, A.S. - BRESVLOEMANS, S.A. - MELCHERS, L.S. - VANDENELZEN, P.J.M. - CORNELISSEN, B.J.C. 1993. Only specific tobacco (Nicotiana tabacum) chitinases and beta-1,3-glucanases exhibit antifungal activity. In Plant Physiology, vol. 101, no. 3 , pp. $857-863$.

STINTZI, A. - HEITZ, T. - PRASAD, V. WIEDEMANNMERDINOGLU, S. - KAUFFMANN, S. - GEOFFROY, P. - LEGRAND, M. - FRITIG, B. 1993. Plant pathogenesis-related proteins and their role in defense against pathogens. In Biochimie, no. 75, pp. 687-706.

TRUDEL, J. - ASSELIN, A. 1989.Detection of chitinase activity after polyacrylamide-gel electrophoresis. In Analytical biochemistry, vol. 178, no. 2, pp. 362-366.
VAN HENGEL, A.J. - TADESSE, Z. - IMMERZEEL, P. SCHOLS, H. - VAN KAMMEN, A. - DE VRIES, S.C. 2001. N-acetylglucosamine and glucosamine-containing arabinogalactan proteins control somatic embryogenesis. In Plant Physiology, vol. 125, no. 4, pp. 1880-1890.

VAN HENGEL, A.J. - VAN KAMMEN, A. - DE VRIES, S.C. 2002. A relationship between seed development, Arabinogalactan-proteins (AGPs) and the AGP mediated promotion of somatic embryogenesis. In Physiologia Plantarum, vol. 114, no. 4, pp. 637-644.

YEH, S. - MOFFATT, B.A. - GRIFFITH, M. - XIONG, F. - YANG, D.S.C. - WISEMAN, S.B. - SARHAN, F. DANYLUK, J. - XUE, Y.Q. - HEW, C.L. - DOHERTYKIRBY, A. - LAJOIE, G. 2000. Chitinase genes responsive to cold encode antifreeze proteins in winter cereals. In Plant Physiology, vol. 124, no. 3, pp. 1251-1263.

ZHONG, R.Q. - KAYS, S.J. - SCHROEDER, B.P. - YE, Z.H. 2002. Mutation of a chitinase-like gene causes ectopic deposition of lignin, aberrant cell shapes, and overproduction of ethylene. In Plant Cell, vol. 14, no. 1, pp. 165-179.

ZUR, I. - GOLEBIOWSKA, G. - DUBAS, E. - GOLEMIEC, E. - MATUSIKOVA, I. - LIBANTOVA, J. MORAVCIKOVA, J. 2013. Beta-1,3-glucanase and chitinase activities in winter triticales during cold hardening and subsequent infection by Microdochium nivale. In Biologia, vol. 68 , no. 2, pp. 241-248.

Received: February 11, 2017 